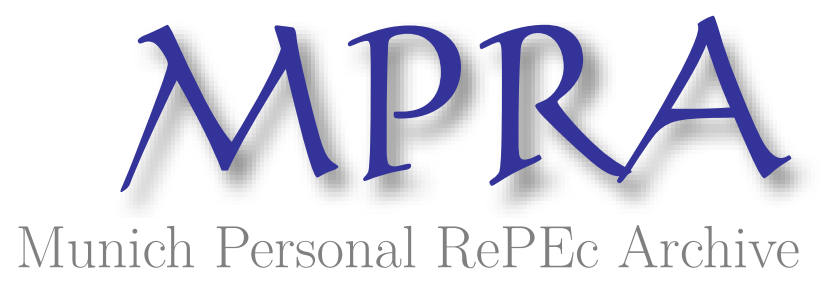

\title{
Russian federalism and post-Soviet integration: Divergence of development paths
}

Libman, Alexander

2009

Online at https://mpra.ub.uni-muenchen.de/12944/

MPRA Paper No. 12944, posted 23 Jan 2009 00:25 UTC 


\title{
Russian Federalism and Post-Soviet Integration: Divergence of Development Paths
}

\author{
by \\ Alexander Libman \\ CDSE Mannheim, IERAS Moscow and ECNU Shanghai
}

January 2009

\begin{abstract}
The paper compares the development of two institutional systems organizing the intergovernmental relations in the former Soviet Union: Russian federalism and post-Soviet regional integration. In spite of common origins, random selections of actors and common development trends in the first decade of their existence, in the 2000s both systems experienced significant divergence. The paper discusses the interaction of four factors explaining differences in the development of post-Soviet integration and Russian federalism: formal vs. informal nature of political property rights of elites; impact of economic asymmetry on political bargaining; role of (potential) federal political arena in terms of interests of territorial elites; and impact of large business groups. It also addresses direct links between the centralization in Russia and the regional integration in the post-Soviet space.
\end{abstract}




\section{Introduction}

The re-centralization trends in the development of the modern Russian federalism have been obvious from 2000 on. The autonomy of regions has been gradually reduced, resulting into the creation of a hierarchical system of governors' appointment from the center. This trend represents just one facet of the process of increasing power concentration in Russian politics. However, the attempts of Moscow to restore its control, though very successful in the intergovernmental relations within Russia, failed completely in the intergovernmental relations between Russia and the former Soviet republics in the Commonwealth of Independent States (CIS). Currently the difference in the results of the development of the socalled "post-Soviet regionalism"1 and of the Russian federalism seems obvious: while Russia turned into a highly centralized federation, where federal government is able to heavily influence the local affairs and limit the authorities of regional governments, the CIS developed itself into a loose association with negligible power. Probably, the experiences of military confrontations in Caucasus clearly demonstrate the differences between the outcomes: it is sufficient to compare the impact of the Chechen war on the autonomy aspirations of Russian regions and of the war in Georgia in 2008 on the relations between Russia and its neighbors in the CIS - while war in Chechnya in 1999 was the first step towards restoring central control over the regional elites, Russia's recognition of Abkhazia and Southern Ossetia seems to discourage even the most "loyal" allies in the post-Soviet space.

However, things which seem to be obvious after two decades were far from being obvious at the beginning. In fact, both post-Soviet regionalism projects and the Russian federalism emerged after the collapse of the Soviet Union as attempts to restructure the postSoviet economic and political space, when both the survival of new independent states and the territorial integrity of Russia were at least questionable. On the one hand, Russian government had to bargain with strong regions, often unilaterally changing the legislation, introducing protectionist measures for the internal market and withholding taxes. But on the other hand, several post-Soviet states seemed to be weak and unable to exist without strong Russian support. The economic and social ties between different regions of Russia were partly less developed than those between regions of new independent states. The formal borders did not seem to be stable: in fact, in the Soviet period the borders between republics within USSR were routinely changed hundreds of times; new republics were established and the status of territories was revised. Several regions of Russia had the status of Soviet republic in the past

\footnotetext{
${ }^{1}$ In this paper "regionalism" refers only to formal cooperation on international arena (as it is used in international relations theory) and not to specifics of center-periphery relations in individual states.
} 
(like Karelia) or even had experience of independence (like Tyva). Just one example of this contradiction: on the one hand, Kazakhstan, an independent state from December 1991, actively supported the re-integration of the post-Soviet space; on the other hand, Tatarstan, an autonomous republic within the Russian Federation, desired further decentralization and larger autonomy. From the point of view of the ethnic composition the share of non-Russian population in several Russian autonomous republics exceeded that in several Soviet republics, where in fact a huge Russian minority was present. During the last seventeen years both institutions (the CIS and the Russia Federation) co-existed in the same economic and political environment

So why did the post-Soviet integration turn out to be an "ink on paper" project, while the Russian federalism gradually developed into a centralized system? This is the question this paper is going to consider. Although the literature dealing with all aspects of Russian federalism has been huge, and there is also substantial body of scholarly research on postSoviet integration, there have been, to my knowledge, no attempts to consider these two institutional systems in a comparative setting. ${ }^{2}$ The paper looks at the interaction of four factors in order to explain the divergence of the development paths: formal vs. informal nature of political property rights of elites; impact of economic asymmetry on political bargaining; role of (potential) federal political arena in terms of interests of territorial elites; and impact of large business groups. It mostly remains in the realm of the rational choice analysis, although it goes without saying that also the nature of academic and social discourse on Russian federalism and post-Soviet integration was completely different and hence was able to influence the results of the development (cf. Tsygankov, 2003, for post-Soviet space, and Fruchtmann, 2003, for Russian federalism).

Hence, the contribution of the paper is threefold. First, the understanding of divergence between post-Soviet integration and Russian federalism is helpful in terms of looking at determinants of political and institutional development of post-Soviet countries in general. Second, the analysis can be instrumental in assessing the stability of the current recentralization trend in the Russian federalism, and understanding the general ability of postSoviet countries to develop a decentralized governance system. Third, there is also a broader

\footnotetext{
${ }^{2}$ There is, however a related literature studying the reasons for the collapse of the Soviet Union as opposed to stability of Russian Federation (for a survey see Latin, 2000); it, however, looks at relatively different economic and political environment (weak central state, economic crisis) as opposed to the integration and federalism divergence studied in this paper. Basically, the question of this literature is why the weak federation USSR collapsed and the weak federation Russia survived; my question is why the weak federation Russia re-emerged as a centralized state, and the weak alliance in the post-Soviet space continued its way to abyss.
} 
interest in comparing the development of international alliances and federations. ${ }^{3}$ The political science, international relations and political economy literature on the stability of alliances and federations has been growing fast in the recent years. Yet there has been little attention to the comparative analysis of alliances and federations, although the topic could be traced back to the seminal contributions of Riker (1964); the existing work mostly deals with emergence of these institutions and transition from alliances to federations (Niou and Ordeshook, 1998, Filippov et al., 2004; Rector, 2006). The post-Soviet area with simultaneous development of both federal and international integration institutions in a similar environment, but with substantially different outcomes provides a good field for comparative analysis.

The paper is organized as follows. The next section reviews the development of the post-Soviet integration and of the Russian federalism. The following section discusses the impact of individual factors determining the development paths of two systems. The fourth section presents some arguments regarding the possible interaction between post-Soviet regionalism and Russian federalism. Finally, the last section concludes.

\section{Russian federalism and post-Soviet integration}

The political system of the Soviet Union was based on the interaction of territorial interests and sectoral hierarchies, which resulted in the establishment of elite networks (Rutland, 1993). The bargaining between these two systems, sometimes referred to as the "administrative market" (Kordonskiy, 2001), determined to a certain extend the shape of policy-making, at least in economic sphere. The crisis of the USSR weakened the vertical industrial structures and often resulted in strengthening the regional elites. At the end of 1991 some of these elites found themselves in the leading positions in new independent state, while others remained part of the Russian Federation (or, to a certain extend other post-Soviet countries, which often experienced a similar problem of territorial fragmentation of elites, see Gel'man, 2008). The new borders simply followed the former internal borders between Soviet republics: thus several regions without strong autonomist sentiment (for example, Central Asia or to a certain extend Belarus) received independence, while others (in particular, republics in the Volga Region and Northern Caucasus) still had the status of subnational

\footnotetext{
${ }^{3}$ The precise distinction between these two forms of intergovernmental relations is difficult. However, as a rule of thumb, one could call a federation an entity where the central authority has supremacy in both domestic and international matters, while in an alliance the states retain their sovereignty (Niou and Ordeshook, 1998:272). In fact, in an alliance the "center" is usually comprised by the representatives of the states, often possessing a veto power. A federation usually develops a more sophisticated institutional structure with direct representatives of the population.
} 
political units. However, the decision on formal dissolution just started the complex set of bargaining between independent and quasi-independent jurisdictions.

Since the development of the Russian federalism is a well-studied phenomenon, let me just briefly describe the main stages in the center-periphery bargaining within the newly drawn Russian borders. The wave of "declarations of sovereignty" of the Soviet republic was quickly mimicked by the autonomous republics in Russia, which were able to gain from the competition between the Soviet and the Russian governments, and, paraphrasing the wellknown statement of Boris Yeltsin, to "swallow" substantial autonomy and political rights. After 1991 the Soviet government left the scene; however, the power struggle between individual groups in the leadership of Russia still left the national republics an influential coalition. During 1991-1993 the republics coordinated their effort in obtaining concessions from the center (Solnick, 2002), especially given the virtually absent political and fiscal constitution. The retention rates were subject to regular re-negotiations between the central and the regional governments. The Federal Treaty of 1992 provided special rights to the republics vis-à-vis other constituents of the Russian Federation. The attempts of other (nonethnic) regions in Russia to gain similar status were, however, unsuccessful.

The political and fiscal reforms of 1993-1994 marked the new stage in the development of Russian federalism: the new constitution officially equalized the powers of all regions in Russia (ethnic and non-ethnic), and the fiscal legislation established a highly centralized federal structure with limited authorities of subnational units. The disproportionate decentralization of spending responsibilities was counteracted by the centralized revenue responsibilities, based on split taxes in the (almost) exclusive authority of the central parliament. The step-by-step establishment of Federal Treasury made the direct manipulations of retention rates impossible. On the other hand, individual territories were still able to gain substantial autonomy beyond the constitutional provisions through the system of bilateral power sharing treaties signed by about half of regions in Russia (Tolz and Busygina, 1997; FIlippov and Shvetsova, 1999; Söderlund, 2003), but also through unilateral actions, mostly in non-fiscal area (individual acts and regulations directly contradicting federal law, see Polishchuk, 1998). Moreover, federal government remained virtually powerless in terms of intervening in internal political process in the regions (which developed quickly diverging political systems and (after the establishment of gubernatorial elections in 1996/97) were partly under control of the Communist opposition, see Belin, 1997). Hence, the constitutional unification and centralization played a limited role compared to post-constitutional asymmetric federalism and de-centralization. The parliamentary elections of 1999 witnessed 
an attempt of regional leaders to influence the Yeltsin succession struggle through the Otechestvo-Vsya Rossiya (OVR) political bloc, but also other political coalitions (like Edinstvo) actively recruited governors as prominent supporters (see Colton and McFoul, 2003, for a survey).

One of the first steps of the new presidency of Vladimir Putin was to limit the autonomy of regions and to restrict the informal decentralization and the regional influence on the central government. Several elements of the federalism reform like introduction of federal districts, re-design of the upper chamber of the Federal Assembly (which previously provided regional leaders a significant impact on the political decision-making) and initiation of the revision of regional legislation were implemented without any significant resistance. In 2002 most of the bilateral treaties between regions and the center were nullified. However, further attempts to increase federal control over regional politics seem to have been less successful (Chebankova, 2005) until 2004, when the direct elections of governors were abolished. Although the first steps of the center in the gubernatorial appointments were cautious (Chebankova, 2006; Petrov, 2006), the autonomy of most regional leaders (with the exception of special status of Chechnya, which exchanged loyalist rhetoric for a very high de-facto independence combined with large transfers from the center) was substantially reduced.

To conclude, the development of the Russian federalism resembled what one may call a "decentralization-recentralization" cycle: from initial period of collective bargaining and increasing autonomy of regions, through the period of bilateral post-constitutional treaties and concessions to the re-establishment of federal control. Interestingly, several post-Soviet countries, although unitary according to their constitution, followed a similar cycle: in Kazakhstan regional governments were able to achieve substantial autonomy in the 1990s, but the center managed to counteract the devolution through territorial and fiscal reform and appointment policies in the 2000s (Cummings, 2000; Melvin, 2001; Jones Luong, 2004); in Ukraine the informal devolution was observed in the early 1990s, but throughout the Kuchma presidency the center was able to manipulate the local elites to partly regain influence (Turovskiy, 1999; Way, 2002), although the general logic certainly changed after the 2004 Orange revolution. ${ }^{4}$ Hence, the decentralization-recentralization cycle may be at least one logical path of development of the Soviet administrative market after collapse of the old hierarchy, and not just an artifact of Russia's size and heterogeneity.

The development of the post-Soviet regionalism projects to certain extend fits the same three main periods, but with different results (cf. Kosikova, 2008). Each period is

\footnotetext{
${ }^{4}$ The de-facto decentralization is even considered as "common" for most post-Soviet countries, including smaller ones (Matsuzato, 2004:238).
} 
marked by new (mostly unsuccessful) attempts to develop instruments of economic and political cooperation between post-Soviet countries. In 1991-1993/94 the cooperation, to a great extend, was determined by a chaotic mixture of remaining Soviet interdependencies and new elements. The countries focused on settling the property disputes and establishing the formal institutions of integration within the CIS. In the economic area the main channel of cooperation was the "Ruble zone", acting as a unilateral currency union between post-Soviet countries. The ideal for cooperation at this point of time was the re-establishment of close economic and political union, even a new federation (Yazkova, 2007), like the Eurasian Union proposed by Kazakhstan. However, the "Ruble zone" did not survive due to the contradictions between post-Soviet countries supporting their economic independence (as part of the "nation-building" component of the "triple transition", see Offe, 1991) and Russia's reluctance to subsidize the economies of other post-Soviet states (Dabrowski, 1995). Similarly, other measures to institutionalize the cooperation between post-Soviet countries turned out to be unsuccessful.

Hence, in the autumn 1993 the post-Soviet countries attempted to revive the cooperation through a new concept, implying the development of regional integration following the pattern of the European Union (Grinberg, 2004), considered as the "blueprint" for any form of regional integration. Unsurprisingly, even the scope of individual agreements mimicked that of the EU, although the order of signing them was often different: CIS members signed the Economic Union agreement, the Payment Union agreement, Customs Union agreement and established the Eurasian Community of Coal and Metals. The attempts to create "a post-Soviet EU" with twelve members, however, were extremely difficult, so countries focused on integration within "smaller clubs", in particular within the Customs Union / Eurasian Economic Community (EAEC: Russia, Kazakhstan, Belarus, Tajikistan and Kyrgyz Republic), the Central Asian Union / Central Asian Economic Community / Organization of Central Asian Cooperation (OCAC: Kazakhstan, Kyrgyz Republic, Tajikistan and Uzbekistan), the Russian-Belarus Union (in different forms - from the Commonwealth of Sovereign States to the "Union State" of Russia and Belarus) and further non-institutionalized groups (Bremmer and Bails, 1998). All these structures of post-Soviet regionalism developed their own supranational bureaucracy, which regularly produced new initiatives and agreements. The post-Soviet countries in different combinations established different farfetched economic and political cooperation structures, which mostly were never implemented, but played an important role in internal politics, providing the incumbents with 
new arguments against opposition (Fel'dman, 2005; Ambrosio, 2006; Allison, 2008). ${ }^{5}$ Hence, this "asymmetric regionalism" with different groups of countries imitating more or less deep integration seemed to meet the expectations of political elites in the region.

The early 2000s witnessed the re-definition of the regionalism in the post-Soviet space. On the hand, the increasing political consolidation in Russia and its larger resources in a period of high oil prices and substantial economic growth supported the interest of its elite towards reviving the influence in the post-Soviet space. In 2003, according to some analysts, the post-Soviet region became the "priority zone" for the Russian foreign politics (Trenin, 2004, 2004a). The new policy implied both maintaining old-fashioned cooperation between elites, supporting each other against opposition, but also an increase of influence of Russia on the policy-making in the post-Soviet space, more pragmatic approach to redistribution of attractive economic assets and development of new institutional structures for regional integration. In particular, the Common Economic Space project (CES: Russia, Ukraine, Kazakhstan and Belarus) in 2003 moved away from the "EU-style" approach towards a more flexible "functional" integration between the countries, without strong supranational institutions and with clear focus on economic opening up. However, Russia's attempts to gain an impact on post-Soviet politics turned into a disaster for Russian political elite after the "Orange revolution" in Ukraine in 2004 (which seems to have been perceived as a serious threat by the Russian leadership, see Ryabov, 2005). The CES was never implemented. The attempts to move from ink on paper integration towards de-facto political and economic influence caused significant problems in Russia's relations with its partners, especially in case of Belarus: mutual accusations of "excessive demands" and "blocking regional integration" became standard practices in the relations of these two countries.

Table 1 provides a short comparative overview of the development of Russian federalism and post-Soviet regionalism. There seem to be certain similarities at the first and the second stage of the development. After a chaotic period of establishing new institutions in 1991-1994, both systems moved towards an "asymmetric federalism / regionalism" structure where individual regions in Russia and individual countries in the post-Soviet space agreed to greater cooperation / centralization. In fact, in both cases rhetoric played a substantial role in the development of institutions; regional and national elites often agreed to exchange the signs of loyalty to Moscow for economic and political support: in terms of direct transfers and control over attractive assets for Russian regions or support against opposition and cheap gas

\footnotetext{
${ }^{5}$ Ambrosio (2006) provides a similar discussion of the Shanghai Cooperation Organization
} 
for post-Soviet countries. ${ }^{6}$ And in both cases the partners attempted to "take advantage" of the weakening regime of Yeltsin in 1998-1999. In Russia the already mentioned OVR provided a coalition of regional leaders to influence the outcomes of presidential elections. In the post-Soviet space Alexander Lukashenko, president of Belarus, strongly supports the integration project, potentially offering him a position of power in Russia itself (or in the new Union State). However, both attempts failed after Vladimir Putin was elected the new president. The similarities are hardly surprising and seem to be driven by the common political-economic environment: for example, weak rule of law and deficit of trust similarly contribute to the decline of internal and international trade on the microlevel and cooperation between political actors.

The divergence seems to start at the third stage of the development. In Russia the attempts of central government to reestablish control were successful and did not meet any significant resistance. In the post-Soviet space, however, Russia's attempt to take a "more active role" in influencing internal politics and fostering economic and security cooperation failed; in fact, post-Soviet countries preferred to "keep a distance" from Moscow. Regional cooperation with Belarus turned into a series of conflicts; Ukraine after the Orange Revolution withdrew from the CES initiative. The relative successes of regional cooperation seem to be clearly motivated by internal political struggles in the post-Soviet countries with Russia's role being a re-active rather than a pro-active one, and also extremely limited: for example, after the Andijan rebellion Uzbekistan agreed to enter the EAEC; however, in 2008, five days after the EU sanctions were removed, the country left the integration group. With Turkmenistan's decision to take the position of an "observer" in the CIS (the observer status is not implied by the CIS Charter) and Georgia's exit from the CIS to become valid in 2009, even the formal "ink on paper" cooperation in the post-Soviet space seems to collapse.

Table 1 about here

However, the reasons for this divergence of institutional development are far from being obvious. It is unlikely to be caused by the composition of participants; in fact, as already mentioned, the groups of "new independent countries" and "Russian regions" were selected to a certain extend randomly according to artificial Soviet borders. It is also unlikely

\footnotetext{
${ }^{6}$ Certainly, the scope of redistribution within Russian Federation was much higher than across the borders of post-Soviet states. However, in several cases (especially Belarus) Russia's support was crucial for economic growth - nevertheless, while in Russia recipient regions often supported centralization and could be used against donor regions, in the CIS the redistribution did not really strengthen Russia's positions.
} 
to be caused by economic divergence: at least at the beginning post-Soviet countries were as linked by the ties of the "Single People's Economy Complex" (Edinyi Narodnokoziastvennyi Komplex) of the USSR as the regions of Russia (see also Motyl, 2001:103). Moreover, both re-centralization project in Russia and regionalism project in the CIS in the 2000s were supported by very high economic growth in the region, which should equally influence the power balance in both systems. The border location and geographical distance from Moscow also does not seem to explain the whole story: many ethnic republics in Russia are border regions (especially in Northern Caucasus, but also in Siberia). The political regimes in Russian regions and in post-Soviet countries are often very similar. Finally, the military threat, as already mentioned, seems to play different role in the "internal" and "international" relations: the war in Chechnya lasted for a decade, but did not lead to any support of separatism from other regions (even the Muslim republics) at the level of the political elites and finally resulted into establishment of a rhetorically loyal regime, while the war in Georgia obviously seems rather to encourage post-Soviet countries to limit their cooperation with Russia than to foster it (Spechler, 2008). So, the puzzle is worth considering.

\section{Factors of divergence}

\subsection{Formal and informal political property rights}

By claiming that the development of the second stage of Russian federalism and postSoviet regionalism exactly paralleled each other, I so far ignored an important dimension, which provided substantial differences between the institutional systems: the design of political property rights, or the rights of regional elites to make unilateral decisions in their regions. As already mentioned, Russian federalism combined the de-facto high decentralization and asymmetric federalism with a de-jure very centralized structure; so, the political property rights provided to regional leaders were mostly of informal nature. On the other hand, even the most ambitious initiatives in the post-Soviet integration did not create any formal commitment of post-Soviet countries to a supranational decision-making procedure: the CIS Economic Union and OCAC used the unanimity rule, the EAEC partly implemented a weighted voting scheme (with Russia's 40 percent votes), which still provided other partners substantial autonomy. In fact, the absolute majority of the agreements in the post-Soviet space has a non-binding nature, or most certainly incorporates no mechanism of enforcement. On the other hand, the international recognition of new independent states assured the formal nature of the political property rights received by their elites. While in the short run the power relations seemed to be more important than this distinction, in the long 
run it turned to be a decisive advantage of post-Soviet countries over even the most “autonomous" Russian regions.

One of the key features of the informal property rights in general is that they are subject to re-negotiation if the power balance supporting their initial distribution is changing. Formal property rights may as well be subject to changes. However, to challenge the formal property rights is costly if there is an enforcement mechanism (and the costs are increasing with the quality of this mechanism). Obviously, the enforcement may be weak; however, it is important to notice that the informal property rights may exist in a lawless environment (and thus constitute the only claims on assets available), but also be present in an environment where formal property rights are specified, but the de-facto control over resources is different. This is the case for the Russian federalism: the regions not just received only informal political property rights - the formal political property rights remained by the federation. In case of the post-Soviet space elites of the new independent states received both formal and informal property rights (with the former originating from their recognized independence and the latter from the weakness of Russia unable to have a strong influence on post-Soviet politics in the 1990s); therefore re-negotiation became even more costly.

The regions in Russia used several instruments to avoid centralized structure of the federalism officially incorporated in the Constitution and the fiscal laws. First, as already mentioned, they designed unilaterally their acts and regulations (including the regional constitutions, see Libman, 2008) in a way often contradicting the federal legislation. In a similar way, multiple power sharing agreements they signed with the federal government and its agencies often went beyond the constitutional provisions. However, the power sharing treaties signed at the later stage of the bilateral bargaining process (from 1996-97 on) mostly incorporated relatively limited autonomy, were standardized and stressed the unity of Russia and the dominance of the federal legislation (Filippov et al., 2004). For example, only the first two treaties (with Tatarstan and Bashkortostan) included provisions redistributing fiscal revenue (Lavrov, 2005). Anyway, even the most advanced early treaties and unilateral devolution of regulation could be theoretically revised by the federal agencies and courts without any large changes in the existing federal law (constitutional or post-constitutional). This is exactly what happened in the first years of Putin's administration.

The second channel of devolution was based on the capture of regional branches of federal agencies. For example, although the tax collection was officially administered by the federation, regional governments managed to establish control over the regional tax authorities. There is empirical evidence that the latter manipulated their tax effort (in terms of 
auditing and collecting taxes or dealing with huge tax arrears accumulated in the economy of the payment deficit) in order to redistribute the de-facto tax revenue in favor of regions (Libman and Feld, 2008). In a similar way, regional governments often controlled other law enforcement agencies and used their power to "shelter" loyal regional enterprises from federal pressure. In this case the simple changes in the appointment policies and re-design of internal hierarchies were sufficient to shift the incentives for local officials of federal ministries. Finally, regions controlled the most attractive resource assets (like the petroleum industry in Bashkortostan or diamond industry in Yakutia). Once again, the redistribution of power implied just shifts in corporate structure of individual businesses. Bahry (2005) shows that the real authority of the regions under Yeltsin remained relatively limited; many of them used different loopholes in federal legislation, which, however, could be (and were under Putin) easily closed. ${ }^{7}$

On the other hand, in case of the post-Soviet countries the political property rights were completely transferred to the national elites at the end of the "claim settlement" process of the early 1990s. The Russian government had no or very limited instruments of direct intervention in the political processes in these states. Basically, it was able to indirectly support some political forces (although this support was obviously conditional on the specifics of the political system, which Russian advisors often failed to understand, as in case of Ukraine) and use economic pressure. However, the latter was also partly costly for the Russian government: while the restrictions on wine trade with Georgia and Moldova in 2006 could be imposed relatively easy and without significant costs for Russia, in the field of energy supply for Belarus or Ukraine the countries were characterized rather by interdependence than by unilateral influence of Russia: restrictions automatically resulted in Russia's inability to meet its obligations of gas supply in Europe and heavy losses. In case of Central Asia the situation was even reversed; Russia depends on the countries of the region in terms of energy supply (if the obligations towards European markets are taken into consideration). In 2008 Kazakhstan, Uzbekistan and Turkmenistan simultaneously requested the increase of gas prices (an unprecedented cooperation between these countries) and were in fact successful. Indeed, Russia was able to increase its influence in specific situations (like in case of internal instability in Tajikistan or external threats in Armenia), but even in these cases, once the power basis of the regimes was consolidated, they immediately tried to reduce

\footnotetext{
7 And it makes the situation in Russia even more similar to the decentralization-recentralization cycles in Kazakhstan and in Ukraine under Kravchuk and Kuchma mentioned above.
} 
dependence from Russia: Tajikistan's attitude towards Russian investors in 2007-2008 shows it clearly. ${ }^{8}$

However, even recognizing that the informal political property rights provided the Russian center with the necessary instrument for recentralization, it is still necessary to understand why regions did not try to "formalize" their position in the 1990s, when they had a substantial influence on federal politics. For example, why did they agree to a formally highly centralized revenue system? Why did they accept the equal treatment in the Constitution? One of the arguments may be that the governors never formed a stable coalition: the autonomy aspirations and the attempts to influence the federal center were the prerogative of a small group of regions (ethnic republics and wealthy "donor" regions), while the rest just tried to benefit from political bandwagon effect, following the more influential group. The decentralization trend of the 1990s in this context is mostly an outcome of ideological preferences and bargaining within the federal elite: after the shifts at the level of the federal center opened the "window of opportunity" for recentralization, the small group of influential governors found itself too weak to influence the federal politics (Gel'man, 2006). From this point of view the elites of the new independent states just received a "gift" of formal political property rights in 1991 (through the collapse of the Soviet Union), which they used throughout the next two decades. In the next two subsections I will consider two further explanations for the observed outcome: the potential benefits of the "federal prize" for regional leaders and the economic asymmetries.

\subsection{The "federal prize" vs. the regional autonomy}

Analyzing the struggle for autonomy between regions and the federal government, it is often important to move away from the static cost-benefit analysis. In the long run regional leaders may hope to "move" on the federal political arena (by directly accepting positions in federal administration or indirectly influencing federal policy). If these hopes are perceived as realistic, regional leaders face a trade-off: on the one hand, increasing regional autonomy now may support their power and increase their rents, but, on the other hand, it reduces the value of the "prize" they are able to capture after successfully moving on the federal level. Or, to put it otherwise, the trade-off is between current rents they receive as regional leaders (which are higher in case of high autonomy) and future rents they receive as federal-level politicians

\footnotetext{
${ }^{8}$ The Russian business group UC RUSAL was engaged in the reconstruction of the Rogun Hydroelectric Power Plant as part of an agreement between governments of Russia and Tajikistan. The project was treated as one of the core initiatives of the group. In 2007, however, the government of Tajikistan unilaterally decided to change the main contractor for the project and to renegotiate its conditions. Similarly, the government of Tajikistan attempts to increase its share in the Sangtudin Power Plant controlled by the Russian Inter RAO UES.
} 
(which are higher in case of low autonomy). This is however an important distinction between federations and international unions. In federations the independent federal political arena exists and can be accessed, at least theoretically, by any regional leader. But in the international union there is no independent center; the decisions are just made through bargaining between countries with more or less substantial influence. While the governor may hope to become president (or install a president whom he will be able to influence), the president of a weaker country usually has no realistic reasons to hope to become president of a stronger country or even influence who will accede to this position. This fundamental difference may lead ceteris paribus to stronger centralization in federations (or, at least, to the substantial de-jure decentralization: in this case regional leaders explicitly take the renegotiation option described above into account, but hope, that they will be those ones who will re-negotiate towards centralization) and to weaker integration and cooperation in international alliances.

This logic can be applied to certain extend to the centralization in the Russian Federation in the early 2000s. As already mentioned, the regional governors became important political actors in the game of succession of Yeltsin in 1999. Although most of them (with the only exception of the Moscow Mayor Yuri Luzhkov) did not pursue any personal ambitions on the federal level, they most certainly aimed to become a strong power participating in the design of federal politics. Anyway, the influential leaders of ethnic republics and donor regions seem to have focused on redistribution of "federal pie" rather than on ensuring higher formal autonomy (what was probably possible in the unstable environment after 1998). Moreover, the alliance of the regional governors, Otechestvo Vsya Rossiya, served as one of the founding elements for the establishment of the Edinaya Rossiya, the "party of power" of Vladimir Putin. This is of course a clear example of the "unintended outcomes of intended actions". In order to increase its influence on the federal political arena, governors needed to institutionalize their coalition, as they did by establishing OVR. The reaction of their opponents in the political elite was the creation of Edinstvo, which, as already mentioned, also partly relied on support of (other) regional governors. However, the appearance of these two parties basically shaped the competition on the federal level in 1999. After the success of Putin became inevitable, a reasonable choice for the governors was to agree with the merger of Edinstvo and OVR; Edinaya Rossiya, however, seems to produce substantial contribution to the centralization (Konitzer and Wegren, 2006).

In case of the post-Soviet space the situation was of course completely different. There exist no "federal political arena" and no political parties spreading the whole region (although 
the communists experimented with international political alliances like the Union of Communist Parties, they also remained ink on paper - like the post-Soviet integration in general). Obviously, presidents of the post-Soviet countries hardly had a chance to have a real influence on the Russian politics. ${ }^{9}$ There is, however, one notable exception, which in fact just provides additional arguments for the claim of this paper: Alexander Lukashenko indeed had a substantial influence on the internal political arena in Russia and was to certain extend considered a potential powerful player in the Russian political game. In fact, the whole development of Russian-Belarus Union seems to be an outcome of interplay of three factors: Yeltsin's attempts to gain additional political support through fostering reunification (widely accepted by the Russian population); Lukashenko's attempts to use the Union as an argument against opposition; and Lukashenko's ambitions to advance to the Russian political scene (for a detailed treatment see Danilovich, 2006). Unsurprisingly, Lukashenko strongly supported the establishment of the position of the president and vice-president of the Union State; given the inherent weakness of the potential Yeltsin presidency, it would provide him as vicepresident with substantial influence. It goes without saying that these ambitions (probably, quite unrealistic even in the 1990s) became completely unachievable under influential and popular president Putin; and indeed, Putin's period coincides with increasing tension between former allies, resulting into a short-term gas war in 2004, permanent struggles over the purchase of the Belorussian gas company Beltransgaz by Gazprom, regular threats of Lukashenko to change the orientation of his country's foreign policy "towards the West", and finally, decision not to recognize Abkhazia and Southern Ossetia and not to support Russia's embargo on wine trade with Georgia and Moldova.

\subsection{Endowment and size asymmetry}

As already mentioned, an often stressed feature of both Russian federalism and the post-Soviet integration is their asymmetric nature. ${ }^{10}$ In Russia a small number of regions concentrate the substantial portion of population, territory, economic potential and natural resources. However, though the Russian Federation is definitively asymmetric in socioeconomic terms, it does not exhibit features of federations with one dominant region, like second German Empire (with Prussia) or early Argentina (with Buenos Aires). In fact,

\footnotetext{
${ }^{9}$ One should notice that there are examples in the post-Soviet world when the weaker partner indeed dominated the political sphere of the stronger one: the special case of Armenia, where substantial part of elite comes from the separatist enclave Nagorny Karabakh in Azerbaijan, which is de-facto treated as an independent state by the republic.

${ }^{10}$ Here I use the term "asymmetry" in the notion of unequal resource endowment; it does not necessary imply asymmetric degree of political autonomy, although it was the result in Russia and in the CIS in the 1990s. In order to describe the latter phenomenon, I use the terms "asymmetric federalism" and "asymmetric regionalism".
} 
according to different dimensions (like resource endowment, territory, population, or industrial production) an extraordinary influence is attributed to different regions: say, to Yakutia in terms of territory, Khanty Mansy Autonomous District in terms of oil resources, Taimyr in terms of non-ferrous metals or City of Moscow in terms of population and financial flows. The post-Soviet space is also highly asymmetric, but in this case a clearly dominant country is present. Russian Federation accounts for about half of the population of the region and concentrates the main advantages in terms of economic potential, natural resources and even its geographical location (especially from the point of view of the landlocked Central Asian countries); the relative power of Russia has always been discussed as one of the major problems of the post-Soviet political and economic cooperation (D'Anieri, 1997; Mayes and Korhonen, 2007).

The fact that the asymmetry is likely to influence the stability of international alliances and federations is well-established in the literature. However, the results of political science and economics differ to certain extend. From the point of view of economics, differences in endowments and population are likely to be associated with heterogeneity of preferences towards (potential) central policies, and therefore make cooperation harder. Different size makes regional integration (Mayer, 1981, Jensen, 1994, Fung and Schneider, 2005), monetary unions (Casella, 1992) and federations (Ellingsen, 1998, Gradstein, 2004) less stable. There are basically two problems of unequal alliances: on the one hand, smaller countries may expect an unsubstantial impact on policy making and hence large political risks from cooperation (or request special institutional arrangements to prevent it, often resulting in lower centralization); on the other hand, the gains from cooperation may be unequally distributed between small and larger countries, resulting in redistribution struggle and reluctance of cooperation. For example, small countries gain in military alliances (Olson and Zeckhauser, 1966) and trade blocs (Casella, 1996); ${ }^{11}$ in this case the larger partners become unwilling to cooperate (Goyal and Staal, 2004). ${ }^{12}$

The political science and international relations results are more heterogeneous, because they assume that the cooperation may be (partly) involuntary and determined through

\footnotetext{
${ }^{11}$ This argument is, however, criticized from empirical standpoint in Badinger and Breuss (2006).

12 Therefore endogenous blocs will form among similar countries (Das and Ghosh, 2006) or gradually (Bond and Park, 2002). If the economic opening up is associated with interregional capital mobility, the preferences of small and large countries may differ because of differentiated effects of tax competition: different models, however, predict different allocation of gains and losses according to size and different preferences with respect to policy harmonization (Bucovetsky, 1991; Wilson, 1991; Kanbur and Keen, 1993; Eggert and Haufler, 1998; Haufler and Wooton, 1999; Forslid, 2005; Stöwhase, 2005; Peralta and van Yperserle, 2005).
} 
power relations. ${ }^{13}$ For international unions the realist approach, like economics, considers asymmetric gains from exchange a factor hindering cooperation (Waltz, 1979), though Pedersen (2002) expands the analysis to explain the institutionalized regional integration as a "cooperative hegemony". Efird and Genna (2002) extend the power transition theory to account for the processes of regional integration and claim that regional integration is more likely after power transition (i.e. increase of power of subordinate partner) if both partners are jointly satisfied with the status quo. But, on the other hand, the hegemonic stability literature in different versions empathizes the importance of hegemonic state as a crucial element for the development of alliances, either because of preference of hegemon for cooperation (Gilpin, 2001) or simply because of his ability to solve collective action problems (Kindleberger, 1973). Moreover, the balance of power approach attributes the development of formal regional agreements to the desire of weaker countries to "bind" the potential hegemon or to provide a countervailing power center (D'Anieri, 1997). The literature on international hierarchies (Lake, 1999) also focuses on unequal power relations as the basis for alliance formation and as an instrument to avoid opportunistic behavior. ${ }^{14}$ Therefore existence of a powerful state in an international union can in fact contribute to its stability. ${ }^{15}$ Finally, the political science literature definitively acknowledges higher instability of federations with asymmetric regions. In particular, the federations with dominant ethnic or territorial unit are claimed to be prone to a "take-over" of the center and thus to secessions (Filippov et al., 2004).

To conclude, the results seem to depend on how the trade-off between the power of the strongest member to re-define the rules of the game in her favor and the asymmetric costs and benefits between large and small are allocated. However, there is to my knowledge no literature trying to compare the impact of the asymmetry on stability and degree of integration in federations and alliances. The specifics of these two institutional forms, according to the definition given in the introduction, is that there is a fundamental difference in the way the conflict over redistribution takes place: while the main conflicts in an alliance are horizontal (between regions), federations are usually driven by vertical conflicts, because the federal

\footnotetext{
${ }^{13}$ Although there is some research in economics which takes power relations and direct pressure into account, e.g. Jones (2007) for international alliances and Bandyopadhyay and Wall (1999) for choice between FTA and customs unions. A somehow similar discussion is present for asymmetries between trade blocs and their market power (Bond and Syropoulos, 1996) and tariff wars between large and small countries (Kennan and Riezman, 1988).

${ }^{14}$ See also the discussion in Kang (2004).

${ }^{15}$ This is a point also accepted by some work in economics (Welfens, 2004) dealing with institutional design of regional integration areas.
} 
center appears as an independent actor with its own redistributive appetites. ${ }^{16}$ Using the comparison from Filippov et al. (2004), it is possible to say that federations are based on an $\mathrm{N}+1$ governments game ( $\mathrm{N}$ regions and the center), while international alliances imply an $\mathrm{N}$ governments game. Combining the power vs. asymmetric gains trade-off with this feature, one in fact is able to hypothesize that the effects of asymmetry are different for alliances and federations, and, even more, possibly non-linear in asymmetry.

Consider first the case of significant asymmetries, i.e. the presence of substantial bargaining power of one region (or country). This is usually the subject of investigation in the literature. The bargaining power can be loosely related to the "exit threat", which is a wellknown factor influencing the design of international alliances (see Blankart and Koester, 2008). For the case of the federation strong asymmetry would result in substantial concessions to individual region, usually associated with strong devolution. However, the stability of the federation is violated, because opening up bargaining with one region often results in a domino effect for other constituents (Boeckenfoerde et al., 2007). In an international alliance the outcome may be different: the strong partner can indeed "pressure" the potential members to cooperate in a way supporting his interests (thus an alliance serves as an institutionalization of an international hierarchy). The difference comes from the main rival of the powerful region or country: in the federation it tries to achieve concession from the center, and in an international alliance from other partners. ${ }^{17}$ In both cases stability is positively correlated with degree of achieved centralization and cooperation.

Table 2 about here

The things, however, change, if there is a weak asymmetry (see Table 2), when the power of the strong region is insufficient to achieve its goals, but the asymmetric gains and costs are still there. Obviously, in an international alliance it results in lower cooperation - as the economics literature predicts. However, it is possible that the stronger partner is too weak to indeed achieve its goals, but too strong to be feared by other partners. In this case it may actually result in a strange combination of lower degree of de-facto cooperation and relative stability of de-jure institutions. On the one hand, deep cooperation is rejected by the weaker partners to avoid dependence from the strong actor. But on the other hand, the weak partners

\footnotetext{
${ }^{16}$ There are of course exceptions like Argentina in the nineteenth century, which was mostly influenced by the horizontal conflict between states, see Gibson and Faletti (2004).

17 This discussion assumes that the alliance or federation is already given: of course, if one looks at their endogenous formation, the situation may be different.
} 
prefer to remain part of the regional structure established by the strong one to avoid provoking direct conflicts. In case of the federation the outcomes are reversed, because the main bargaining partner for 'not so strong' region is the federal government. On the one hand, powerful regions are not influential enough to completely re-design the federal policy. In this case the federation can actually increase the degree of centralization to successfully control the potential influential actors (China's policy towards more developed provinces may be a good example, see Sheng, 2007). However, this imbalance may be even more encouraging the secession than the case of substantial concessions to the really strong regions; the question is the balance of perceived and actual costs and benefits, which can be easily miscalculated. So, the weak asymmetry may make federations more centralized, but less stable, than the federations without asymmetries.

The experience of the post-Soviet federalism and regionalism fits this notion of weak asymmetry. Russia's ability to really influence the political processes in the post-Soviet countries (or to act as a regional hegemon) has been limited throughout the 1990s, and, as the experience of Ukraine and Georgia shows, remained unsubstantial in the 2000s. Initially the limited impact was related to internal political conflicts in Russia (with politics in the "near abroad" being a constant field of contradictions between the president and the communist opposition); however, factors like deficit of expert knowledge (recognized even by the representatives of Putin's administration, see Kolerov, 2006) and the already discussed lack of effective pressure instruments remained in force even in 2000. Nevertheless, Russia was obviously strong enough to cause suspicions by the post-Soviet leaderships. Therefore, on the one hand, many post-Soviet countries remained extremely reluctant to support any form of developed regionalism (Ukraine, Azerbaijan or Uzbekistan), while others restricted themselves to rhetorical cooperation (Belarus). However, the post-Soviet regionalism turned out to be surprisingly stable: in fact, countries repeatedly established new (non-functional) institutions on the basis of old (non-functional) ones. These permanent attempts of pseudointegration may result exactly from this combination of weak asymmetry; a direct conflict against Russia was undesirable (in fact, even Georgia remained part of the CIS until the war in summer 2008, although the decision to leave the Commonwealth was announced several times), but on the other hand, any developed cooperation should also be avoided.

The Russian federalism may also be treated from the point of view of weak asymmetry. As already mentioned, the secessionist potential of the majority of Russian regions was in fact relatively limited, as well as the de-facto influence of individual governors. Moreover, the extremely strong economic position of the City of Moscow (which 
comes especially close to resembling the impact of Prussia or Buenos Aires Province) is a clear function of its position in a centralized state, where the capital receives special benefits. Thus the center indeed was able to apply selective pressure mechanisms against potential "troublemakers". Libman and Feld (2008) demonstrate that since 1995 the retention rates were in fact negatively correlated with the share of non-Russian population in the regions. The internal conflicts at the federal level and the economic crisis restricted the ability of the center to manipulate the governors; however, under Putin the de-jure centralized federalism was enforced into practice and even extended by new mechanisms of central control. On the other hand, Russia did experience an attempt of unsuccessful secession in Chechnya, which to a certain extend resulted exactly from the miscalculation of costs and benefits of secession by the federal government and the region (although in most cases the separatist activism of regions in the 1990s seems to be rather an instrument of bargaining with the federal center than a true attempt of secession (Treisman, 1997), the misperception of costs and benefits can indeed lead to an open conflict even in case of rational actors). In the 2000 s, when the federal control increased, the conflict seems to have spread over the whole Northern Caucasus, covering other republics originally not involved in the war (Malashenko, 2005).

Differences in the nature of main redistribution conflict also interact with another distinctive feature of the Russian Federation. While there are only twelve actors in the postSoviet space, throughout the 1990s Russia included 89 regions, in particular 21 ethnic republics. The traditional argument of international political economy is that large groups of countries systematically fail to achieve cooperation because of high costs of consensus. The problem was recognized by the designers of post-Soviet regionalism relatively early, and, as already mentioned, numerous smaller "subregional" groups like EAEC or OCAC emerged; however, even in these cases the success of regional integration remains limited. However, for a federation where the main line of bargaining is that between center and regions, the high number of subnational units may have a different effects; it increases the costs of coalition formation against federal center and therefore weakens the position of regions in bargaining. Once again, the coalition of ethnic republics collapsed in the mid-1990s; the federal center actively used the contradictions between regions to increase its influence, as it happened in the OVR / Edinstvo struggle. Moreover, regions demonstrated very weak performance in terms of developing subnational associations (see Stack, 1998:9): although several large coalitions were formed, they had only limited influence on federal politics. So, while in the post-Soviet space formation of smaller alliances was insufficient to achieve higher cooperation and thus supported disintegration, in the Russian Federation the latter did not 
emerge, and the high number of regions - indeed failing to achieve cooperation among themselves - in fact resulted in higher centralization.

\subsection{The role of corporate interests}

The final factor to be mentioned is the role of private businesses as lobbyists in the process of bargaining between countries or between regions and the center. The outcome of "asymmetric federalism" of the 1990s was, as already mentioned, a system of "protected" regional corporations, usually maintaining close ties to governors and presidents and controlling the most attractive assets. Few large multiregional groups were just loose conglomerates of assets (Zubarevich, 2005). The state-owned business groups, although present in all regions, were weakly governed and hardly controlled by the federal government, therefore also unable to prevent the fragmentation of markets. In a similar way the attempts to foster cooperation between economic agents in the post-Soviet space resulted in establishment of formal "transnational financial-industrial groups" without any significant influence on economic decision-making and with strong focus on receiving support from the governments. The situation changed substantially after the crisis of 1998: since the cheap income opportunities through acquiring federal bonds disappeared, business groups had to seek new opportunities of growth, which were connected with regional presence. The expansion of large business groups took place in the period between 1998 and 2002 (Zubarevich, 2002). There seems to be strong evidence that it had a substantial influence on recentralization: regions where interregional corporations were the main lobbyists exhibited a lower degree of protectionism (Guriev et al., 2007) and became less prone to enter the conflicts with the federal center (Speckhardt, 2004).

The expansion of Russian business groups across the borders of the post-Soviet states started several years later; although large corporations like Gazprom and LUKoil acquired their assets in post-Soviet countries (Belarus and Azerbaijan) already in the 1990s, the fullscale increase of Russian business presence in the post-Soviet world was observed from 20012002 on. The regionalization in the post-Soviet space, driven by corporate investments rather than by formal agreements, is still a topic worth detailed empirical investigation. The quality of formal statistics regarding foreign direct investments originating from Russia is notoriously low; the studies looking at corporate and press information on mergers and acquisitions (see Crane et al., 2005; Vahrta, 2005; Libman and Kheyfets, 2008) indicate, however, a significant presence of Russian corporations in the key industries of the post-Soviet countries, in particular resources and telecommunications. There seems to be little correlation between 
these investment flows and formal integration agreements: for example, Russian business has established important positions in Ukraine, which has always been reluctant to advance regional integration, while in other countries like Belarus and Kazakhstan the role of Russian corporations remained limited until late 2000s.

Nevertheless, from the point of view of this paper the really interesting feature is that Russian corporations expressed relatively little interest in supporting their expansion by development of formal regionalism structures and even by informal support of Russian government (though the latter was required occasionally). In fact, businesses remained extremely skeptical towards the perspectives of formal cooperation in the CIS, stressing the need to solve more applied problems. Moreover, the correlation between Russian political influence and Russian FDI is far from being absolute: although there have been attempts to use Russian businesses as a mean of political pressure on the post-Soviet countries (especially in the field of oil and gas, where the decisions of large players are heavily influenced by political logic - the reappearing gas wars between Russia, Ukraine and Belarus are just one example of it), and in some cases worsening political relations resulted in loss of assets or business opportunities (like the Mosyr Petroleum Refinary, which was nationalized by the government of Belarus in 2006), these situations have a still limited scope as opposed to the full scale of investment expansion. For example, Russian business continued actively exploring the Ukrainian markets after the Orange revolution (Kheyfets and Libman, 2008).

So why did the business groups pursue different strategies in terms of supporting cooperation and integration in their internal and international expansion? Unfortunately, there is very limited empirical evidence to be unambiguously applied; however, some speculations may be possible. It looks like the business expansion in Russian regions coincided with a relatively short period between the weakening of the regional business groups (first in turn of the crisis and then after the first federalism reform) and the new wave of nationalization starting with the Yukos deal in 2003 and the banking crisis in $2004 ;{ }^{18}$ so the business groups and the federal government were looking for mutual support (as it is demonstrated by the practice of economic reforms of the early Putin period, see Jones Luong and Weinthal, 2004). The situation, however, changed dramatically after the Yukos deal - and it was exactly the period when Russian corporations increased their attention to the post-Soviet countries. In fact, there is some evidence that at least some of the investment projects abroad were driven by the desire to "diversify" the business activity in presence of potential nationalization threat

\footnotetext{
${ }^{18}$ Although the attacks on the business empires of Vladimir Gusinskiy and Boris Berezovskiy happened earlier, they were still treated as an exception, since both oligarchs were strongly involved in the elections struggle in 1999-2000.
} 
and high dependence from the government in Russia (Yakovlev, 2005). Anyway, the business became much more reluctant to develop a close association to the governmental policy. Obviously, the increasing governmental influence on Russian economy also increased the dependence of Russian businesses on political objectives, but in the area of foreign direct investments even in the late 2000s there was little evidence of strong and unambiguous connection between political goals and investments of private businesses (Vahrta, 2007).

\section{Factors of interdependence}

The comparison of development of Russian federalism and post-Soviet integration implemented so far did not consider the fact that the development of both institutional systems was not independent from each other. Obviously, there are common factors (like the general economic conditions or the nature of political regimes) influencing both systems of intergovernmental relations. However, there are also direct links between the development of Russian federalism and post-Soviet integration, which this section aims to discuss. In fact, given the relatively artificial nature of Soviet "internal" borders between the republics, crossing both economically connected zones and traditional areas of ethnic groups, the existence of spillovers is hardly surprising. In individual regions, like Caucasus, the relations of ethnic republics in the Russian Federation with the center and of Transcaucasian independent states with Russia had a strong influence on each other (Coppieters, 1996; Tsygankov, 2006; Markedonov, 2006). For example, the flows of migrants from ethnic conflicts and economic turbulences in the region often cross the border between the Northern and the Southern Caucasus. Several republics of Northern Caucasus have their own interests across the Russian border (for example, strong connections exist between Northern and Southern Ossetia, ethnic links are present between Adygeya and Abkhazia). Thus, Russian center had to take the potential effect of its policy towards Georgia or Azerbaijan on situation in its own ethnic republics into account. ${ }^{19}$ Moreover, there seems to be some evidence that until 2004 (Ukrainian orange revolution) Russian political elite designed its policy towards the CIS countries and ethnic republics according to the same principles, as if there were a time lag in perception of independences of post-Soviet states (Portinkov, 2006).

The centralization in Russia in the 2000s, as well as similar trends in several other post-Soviet countries may have contributed to the deficit of regional integration. It is well

\footnotetext{
${ }^{19}$ Indeed, this feature seems to be understood even at the formal level: the special commission of the Council of Federation for Northern Caucasus to be established in 2009 aims to include delegates of regional parliaments of ethnic republics of Northern Caucasus, but also of parliaments of Georgia, Armenia, Azerbaijan, Southern Ossetia and Abkhazia (Vedomosti, 2008, December 12)
} 
known that non-democracies often face significant problems in developing cross-border cooperation, mostly because of the lacking ability to provide credible commitments and reluctance of political elites to restrict their power through the establishment of international institutions. Their ability to cooperate is to a certain extend a function of their weakness, when concessions are the only way to ensure political survival. From this perspective increasing centralization in the center-periphery relations most certainly was perceived by the leaders as an indicator of strength and thus reduced the desire to engage in international cooperation. On the other hand, recentralization in Russia strengthened the post-Soviet countries' fear of their stronger partner (although, as it was demonstrated above, did not in fact provide Russia with additional instruments of influence). Therefore, observing the destiny of subnational leaders in Russia, post-Soviet regimes became more reluctant to develop long-term cooperation with the Russian Federation.

The argument was supported by often fears of "incorporation" of individual regions in Russia, either voluntary or not, which sometimes increased through the changes of Russian regional legislation, for example, the new act on formation of regions of 2001 (Kurdiukov and Malfliet, 2001) or mergers of regions (Baev, 2006) and was especially pronounced in case of Russian-Belarus Union and relations to separatist enclaves in the neighboring countries. The experience of Abkhazia and Southern Ossetia may to certain extend support this fears, although formal incorporation of these territories seems so far to be out of question. Zakharov (2008) even claims that Russia specifically preserved the de-jure federalist structure under Putin as an instrument of potential territorial expansion, facilitating incorporation of new regions. This way of reasoning certainly overestimates the ability of the federal center to design the political system of the country according to its will, but may have at least some validity.

\section{Conclusion}

The aim of the paper was to understand the divergence of the development of the postSoviet regional integration projects and the Russian federalism. While in the 1990s both regional integration and center-region relations in Russia followed a similar path of decentralization and disintegration, probably driven by similar political and economic environment, in the 2000s the trends diverged: Russia experienced strong centralization and increase of influence of the central authority, but the post-Soviet regionalism, in spite of Russia's attempts to revive it, collapsed completely. Since the selection of actors in these two treatments was relatively random, and the degree of initial economic interdependence was 
relatively similar, this divergence constituted a puzzle worth exploring. The paper claims that the differences between these two systems of intergovernmental relations resulted from the degree of formalization of political property rights, which, in turn, was an outcome of the structural differences between federations and international unions. On the one hand, the weak asymmetry in Russia reduced the ability of regions to achieve significant autonomy in the 2000s, but supported the fear of secession in the federal center, resulting in stronger control over regions; in the CIS the same feature reduced the ability of Russia to implement its interests in post-Soviet countries, but supported the fear of Russian expansionism in postSoviet elites. Similarly, the (non-)existence of a "federal prize" for ambitious politicians had an impact on choices and bargaining strategies of regional and national elites. Finally, the role of large Russian business groups in Russian regions and in post-Soviet states was different. Moreover, the very process of centralization in Russia seems to have a direct impact on relations to other post-Soviet countries.

As already mentioned, this paper addressed three groups of questions. First, the understanding how post-Soviet integration and Russian federalism diverged is helpful for the analysis of driving forces of economic and political development in the post-Soviet world. This is a relevant question: it goes without saying that the current centralization in Russia has a profound impact on economic reforms, quality of institutions and degree of rent-seeking. Moreover, the structure of economic and political ties between post-Soviet countries also contributes to the incentives to implement reforms and to the survival of incumbent regimes. The identification of four factors presented above can therefore be of interest. Second, the analysis demonstrated some systematic differences between international alliances and federations. It showed that the very fact that in a federation an independent "central" policy arena is present influences the degree of stability and centralization of the structure, even if other economic and political conditions between alliances and federations are the same. The paper also looked at potential different impact of asymmetries among constituents. Obviously, an analysis of just two cases is insufficient to establish general regularities; yet it can at least contribute to development of hypotheses. Finally, the discussion of this paper provides some insights regarding the systematic nature of the current centralization in Russia and other postSoviet countries. It looks like centralization trend is caused by the particular organization of political system rather than to some general path dependencies or even cultural factors; without the (even very weak) central political arena and with formal political property rights it should not necessarily be sustainable. 


\section{Literature}

Allison, Roy (2008): Virtual Regionalism, Regional Structures and Regime Security in Central Asia. Central Asian Survey 27(2):185-202

Amrbosio, Thomas (2006): The Political Success of Russia-Belarus Relations: Insulating Minsk from a Color Revolution. Demokratizatsiya 14(3):407-434

Ambrosio, Thomas (2008): Catching the 'Shanghai Spirit': How the Shanghai Cooperation Organization Promotes Authoritarian Norms in Central Asia. Europe-Asia Studies 60(8):1321-1344

Badinger, Harald, and Fritz Breuss (2006): Country Size and Gains from Trade Bloc Enlargement: An Empirical Assessment for the European Community. Review of International Economics 14(4):615-631

Baev, Pavel K. (2006): Russian Quasi-Federalism and Georgia's Non-Existent Territorial Integrity. Central Asia - Caucasus Analyst, March 5

Bahry, Donna (2005): The New Federalism and the Paradoxes of Regional Sovereignty in Russia. Comparative Politics 37:127-146

Bandyopadhyay, Subhayu and Howard J. Wall (1999): Customs Union or Free Trade Area? The Role of Political Asymmetries. Review of International Economics 7(4):665-672

Belin, Laura (1997): Russia's 1996 Gubernatorial Elections and the Implications for Yeltsin. Demokratizatsiya 5(2):165-184

Blankart, Charles B., and Gerrit B. Koester (2008): Refocusing the EU Budget - an Institutional View. Mimeo

Boeckenfoerde, Markus, Dann, Philipp, and Verena Wiesner (2007): Max Planck Manual on Different Forms of Decentralization. Heidelberg

Bond, Eric W., and Constantinos Syropoulos (1996): The Size of Trading Blocs: Market Power and World Welfare Effects. Journal of International Economics 40:411-437

Bond, Eric W., and Jee-Hyeong Park (2002): Gradualism in Trade Agreements with Asymmetric Countries. Review of Economic Studies 69: 379-406

Bremmer, Ian, and Alyson Bailes (1998): Sub-Regionalism in the Newly Independent States. International Affairs 74(1):131-147

Bucovetsky, Sam (1991): Asymmetric Tax Competition. Journal of Urban Economics 30: 167-181

Casella, Alessandra (1992): Participation in a Currency Union. American Economic Review 82:847-863

Casella, Alessandra (1996): Large Countries, Small Countries and the Enlargement of Trade Blocks. European Economic Review 40:389-415

Chebankova, Elena (2005): The Limitations of Central Authority in the Regions and the Implications for the Evolution of Russia's Federal System. Europe-Asia Studies 57(7):933-949

Chebankova, Elena (2006): The Unintended Consequences of Gubernatorial Appointments in Russia, 2005-6. Journal of Communist Studies and Transition Politics 22(4):457-484

Colton, Timothy J., and Michael McFoul (2003): Popular Choice and Managed Democracy: The Russian Elections of 1999 and 2000. Brookings Institution Press

Coppieters, Bruno (ed., 1996): Contested Borders in the Caucasus. Brussels: Vub Brussels University Press

Crane, Keith, Peterson, D.J., and Olga Oliker (2005): Russian Investment in the Commonwealth of Independent States. Eurasian Geography and Economcis 46(6):405-444

Cummings, Sally N. (2000): Kazakhstan: Centre-Periphery Relations. London: Royal Institute of International Affairs

D’Anieri, Paul (1997): International Cooperation among Unequal Partners: The Emergence of Bilateralism in the Former Soviet Union. International Politics 34:417-448

Dabrowski, Marke (1995): The Reasons of the Collapse of the Ruble Zone. Unpublished manuscript, CASE

Danilovich, Alex (2006): Russian-Belarus Integration: Playing Games behind the Kremlin Wall. Ashgate

Das, Satya P., and Subhadip Ghosh (2006): Endogenous Trading Bloc Formation in a North-South Global Economy. Canadian Journal of Economics 39: 809-830

Efird, Brian, and Gaspare M. Genna (2002): Structural Conditions and the Propensity for Regional Integration. European Union Politics 3:267-295

Eggert, Wolfgang, and Andreas Haufler (1998): When Do Small Countries Win the Tax Wars? Public Finance Review 26:327-361

Ellingsen, Tore (1998): Externalities versus Internalities: A Model of Political Integration. Journal of Public Economics 68:251-268

Fel'dman, Dmitriy (2005): Politicheskoe Vzaimodeistvie Elit Stran SNG. POLIS (4):89-98

Filippov, Mikhail, and Olga Shvetsova (1999): Asymmetric Bilateral Bargaining in the New Russian Federation: A Path-Dependence Explanation. Communist and Post-Communist Studies 32:61-76

Filippov, Mikhail, Ordershook, Peter C., and Olga Shvetsova (2004): Designing Federalism: A Theory of SelfSustainable Federal Institutions, Cambridge

Forslid, Rikard (2005): Tax Competition and Agglomeration: Main Effects and Empirical Implications. Swedish Economic Policy Review 13:113-137 
Fruchtmann, Jakob (2003): Der russische Föderalismus unter Präsident Putin: Diskurse - Realitäten. PhD Thesis, University of Bremen

Fung, K.C., and Patricia Higino Schneider (2006): Asymmetric Integration. International Journal of Applied Economics 2:83-110

Gel'man, Vladimir (2006): Vozvrashenie Leviafana? Politika Recentralizatsii v Sovremennoi Rossii. POLIS (2):90-109

Gel'man, Vladimir (2008): Out of the Frying Pan, Into the Fire? Post-Soviet Regime Changes in Comparative Perspective. International Political Science Review 29(2):157-180

Gibson, Edward L., and Tulia G. Falleti (2004): Unity by the Stick: Regional Conflict and the Origins of Argentine Federalism. In: Gibson, Edward L. (ed.): Federalism and Democracy in Latin America. Baltimore

Gilpin, Robert (2001): Global Political Economy: Understanding the International Economic Order. Princeton University Press

Goyal, Sanjeev, and Klaas Staal (2004): The Political Economy of Regionalism. European Economic Review 48:563-593

Gradstein, Mark (2004): Political Bargaining in a Federation: Buchanan Meets Coase. European Economic Review 48:983-999

Grinberg, Ruslan (2004): Integration und Desintegration im postsowjetischen Raum, in Cassel, Dieter, and Paul J.J. Welfens, P.J.J. (eds.): Regionale Integration und Osterweiterung der Europäischen Union, Stuttgart, Lucius \& Lucius

Guriev, Sergei M., Yakovlev, Evgeny, and Ekaterina Zhuravskaya (2007): Inter-Regional Trade and Lobbying. CEFIR Working Paper 100

Haufler, Andreas, and Ian Wooton (1999): Country Size and Tax Competition for Foreign Direct Investments. Journal of Public Economics 71:121-139

Jensen, Henrik (1994): Sustaining Policy Coordination Between Economies of Different Size. Journal of International Economics 289-307

Jones Luong, Pauline (2004): Economic Decentralization in Kazakhstan: Causes and Consequences. In: Jones Luong, Pauline (ed.): The Transformation of Central Asia, Ithaca: Cornell University Press

Jones Luong, Pauline, and Erika Weinthal (2004): Contra Coercion: Russian Tax Reform, Exogenous Shocks and Negotiated Institutional Change. American Political Science Review 98(1):139-152

Jones, Philip (2007): Colluding Victims: A Public Choice Analysis of International Alliances. Public Choice 132:319-332

Kanbur, Ravi, and Michael Keen (1993): Jeux Sans Frontieres: Tax Competition and Tax Coordination when Countries Differ in Size. American Economic Review 83(4):877-892

Kang, David C. (2004): The Theoretical Roots of Hierarchy in International Relations. Australian Journal of International Affairs 58(3):337-352

Kennan, John, and Raymond Riezman (1988): Do Big Countries Win Tariff Wars? International Economic Review 29(1):81-85

Kindleberger, C.P. (1973): The World in Depression: 1929-1939. Berkley: University of California Press

Kheyfets, Boris, and Alexander Libman (2008): Korporativnaya Integraciya: Al'ternativa dlya Postsovetskogo Prostranstva. Moscow: LKI

Kolerov, Modest (2007): Chto My Znaem o Postsovetskikh Stranakh? Accessed online at < http://www.polit.ru/lectures/2006/07/04/kolerov.html>, January 3, 2008

Konitzer, Andrew, and Stephen K. Wegren (2006): Federalism and Political Recentralization in the Russian Federation: United Russia as the Party of Power. Publius: The Journal of Federalism 36(4): 503-522

Kordonskiy, Simeon (2001): Administrativnye Rynki SSSR i Rossii. Moscow: OGI

Kosikova, Lidia (2008): Itogi Pyatnadtsatiletnego Razvitiya Gosudarstv SNG i Ikh Vsaimnogo Sotrudnichestva. Kontinent Partnerstva (5):36-48

Kurdiukov, Gennadi, and Katlijn Malfliet (2007): Integration by Absorption: New Subjects for the Russian Federation, in: Malfliet, Katlijn, Verpoesten, Lien, and Evgeny Vinokurov (eds.): The CIS, the EU, and Russia: Challenges of Integration. London: Palgrave Macmillan

Lake, David (1999): Entangling Relations: American Foreign Policy in This Century. Princeton University Press

Latin, David (2000): Post-Soviet Politics. Annual Review of Political Science 3:117-148

Lavrov, Aleksei (2005): Budzhetnaya Reforma v Rossii: Ot Upravlenia Zatratami k Upravleniu Resultatami. Moscow: IROF

Libman, Alexander (2008): Constitutions, Regulations, and Taxes: Contradictions of Different Aspects of Decentralization. Mimeo

Libman, Alexander, and Lars P. Feld (2008): Strategic Tax Collection and Fiscal Decentralization: The Case of Russia. Mimeo

Malashenko, Aleksei (2005): Glavnyi Itog Chechenksikh Vyborov: Dve Vertikali Vlasti. Brifing Moskovskogo Centra Karnegi 7(11) 
Markedonov, Sergei (2006): Kavkaz v Poiskakh "Svoei Zemli”: Etnichnost' i Konflity v Regione. Svobodnaya Mysl (4):70-76

Matsuzato, Kimitaka (2004): A Populist Island in the Ocean of Clan Politics: The Lukashenka Regime as an Exception among CIS Countries. Europe-Asia Studies 56(2):235-261

Mayer, Wolfgang (1981): Theoretical Considerations on Negotiated Tariff Adjustments. Oxford Economic Papers 33: 135-153

Mayes, David G., and Vesa Korhonen (2007): The CIS - Does the Regional Hegemon Facilitate Monetary Cooperation. BOFIT Discussion Paper No. 17

Melvin, Neil J. (2001): Patterns of Centre-Regional Relations in Central Asia: The Cases of Kazakhstan, the Kyrgyz Republic, and Uzbekistan. Regional and Federal Studies 11(3):165-193

Motyl, Alexander J. (2001): Imperial Ends: The Decay, Collapse, and Revival of Empires. New York: Columbia University Press

Niou, Emerson M.S., and P.C. Ordeshook (1998): Alliances versus Federations: An Extension of Riker's Analysis of Federal Formation. Constitutional Political Economy 9:271-288

Offe, Claus (1991): Capitalism by Democratic Design? Democratic Theory Facing the Triple Transition in East Central Europe. Social Research 58:865-892

Olson, Mancur, and Richard Zeckhauser (1966): An Economic Theory of Alliances. Review of Economics and Statistics 48: 266-279

Peralta, Susan, and Tanguy van Ypersele (2005): Factor Endowment and Welfare Levels in an Asymmetric Tax Competition Game. Journal of Urban Economics 57:258-274

Pedersen, Thomas (2002): Cooperative Hegemony: Power, Ideas and Institutions in Regional Integration. Review of International Studies 28:677-696

Petrov, Nikolai (2006): Naznacheniya Gubernatorov: Itogi Pervogo Goda. Brifing Moskovskogo Centra Karnegi $8(3)$

Polishchuk, Leonid (1998): Rossiiskaia Model’ Peregovornogo Federalisma (Politiko-Ekonomicheskii Aspekt), Voprosy Ekonomiki (3):68-88

Portinkov, Vitaliy (2006): Mif Umer - Da Zdravstvuet Mif! Neprikosnovennyi Zapas (6)

Rector, Chad (2006): Federalism and International Organizations. Mimeo

Riker, William (1964): Federalism: Origin, Operation, Significance. Boston: Little Brown

Rutland, Peter (1993): The Politics of Economic Stagnation in the Soviet Union: The Role of Local Party Organs in Economic Management. Cambridge

Ryabov, Andrei (2005): Moskva Prinimaet Vyzov Tsvetnykh Revoluciy. Pro et Contra 9(1):18-27

Sheng, Yumin (2007): Global Market Integration and Central Political Control: Foreign Trade and Intergovernmental Relations in China. Comparative Political Studies 40(4): 405-434

Söderlund, Peter (2003): The Significance of Structural Power Resources in the Russian Bilateral Treaty Process 1994-1998. Communist and Post-Communist Studies 36:311-324

Solnick, Steven L. (2002): Federalism and State-Building: Post-Communist and Post-Colonial Perspectives. In: Reynolds, A. (ed.): The Architecture of Democracy: Constitutional Design, Conflict Management, and Democracy. Oxford University Press

Spechler, Martin C. (2008): Is Russia Winning in Central Asia? Paper presented at the conference on "Institutions, Institutional Change, and Economic Performance in Central Asia", Göttingen, Germany, September

Speckhard, Christopher Tomas (2004): The Ties that Bind: Big Business and Center-Periphery Relations in the Russian Federation. PhD Thesis at University Texas at Ausin

Stack, Graham (1998): Neoinstitutionalist Perspectives on Regionalization in Russia. Arbeitspapier des Osteuropa-Instituts der FU Berlin No. 21

Stöwhase, Swen (2005): Asymmetric Capital Tax Competition with Profit Shifting. Journal of Economics 85(2):175-196

Tolz, Vera, and Irina Busygina (1997): Regional Governors and the Kremlin: The Ongoing Battle for Power. Communist and Post-Communist Studies 30:401-426

Treisman, Daniel S. (1997): Russia's „Ethnic Revival“" The Separatist Activism of Regional Leaders in a PostCommunist Order. World Politics 49:212-249

Trenin, Dmitriy (2004): Identichnost' i Integraciya: Rossiya i Zapad v XXI veke. Pro et Contra 8(3):9-22

Trenin, Dmitriy (2004a): Rossiyskaya Vneshnyaya Politika Posle Beslana. Brifing Moskovskogo Centra Karnegi $6(11)$

Tsygankov, Andrei (2003): Mastering Space in Eurasia: Russia's Geopolitical Thinking after the Soviet BreakUp. Communist and Post-Communist Studies 36:101-127

Tsygankov, Andrei (2006): If Not By Tanks, Than By Banks? The Role of Soft Power In Putin's Foreign Policy. Europe-Asia Studies 58(7):1079-1099

Turovskiy, Rostislav (1999): Sravnitel'nyi Analiz Tendencii Regional'nogo Razvitiia Rossii i Ukrainy. POLIS (6):49-61 
Vahtra, Peeter (2005): Russian Investments in the CIS - Scope, Motivation and Leverage. Electronic Publication of the Pan-European Institute, Turku School of Economics, No.9

Vahtra, Peeter (2007): Expansion or Exodus? - The New Leaders among the Russian TNCs. Electronic Publication of the Pan-European Institute, Turku School of Economics, No. 13

Walt, Stephen (1987): The Origin of Alliances. Ithaca: Cornel University Press

Waltz, Kenneth (1979): Theory of International Politics. New-York: McGraw-Hill

Way, Lucan A. (2002): The Dilemmas of Reform in Weak States: The Case of Post-Soviet Fiscal Decentralization. Politics and Society 30(4):579-598

Welfens, Paul J.J. (2004): Regionale Integration in der Ordnungs-, Aussenwirtschafts- und Wachstumstheorie, in: Cassel, Dieter, and Paul J.J. Welfens (eds.): Regionale Integration und Osterweiterung der Europäischen Union. Stuttgart: Lucius \& Lucius

Wilson, John D. (1991): Tax Competition with Interregional Differences in Factor Endowments. Regional Science and Urban Economics 21:423-451

Yakovlev, Andrei (2005): Evolutciya Strategiy Vzaimodeistviya Biznesa i Vlasti v Rossiyskoy Ekonomike. Rossiyskiy Zhurnal Menedzhmenta 3(1):27-52

Yazkova, Alla (2007): Sodruzhestvo Nezavisimykh Gosudarstv: Stranicy Istorii. Informacionno-Analiticheskiy Biulleten Centra Problem Integracii IE RAN (1): 40-54

Zakharov, Andrei (2008): Imperskiy Federalizm. Neprikosnovennyi Zapas (1)

Zubarevich, Nataliya (2002): Prishel, Uvidel, Pobedil? (Krupnyi Biznes i Regional'naya Vlast'). Pro et Contra 7(1):107-119

Zubarevich, Nataliya (2005): Krupnyi Biznes v Regionakh Rossii: Territorial'nye Strategii Razvitia i Social'nye Interesy. Moscow: NISP 
Table 1: Post-Soviet integration and Russian federalism: a comparison

\begin{tabular}{|c|c|c|c|c|}
\hline \multirow[t]{2}{*}{ Period } & \multicolumn{2}{|c|}{ Russian federalism } & \multicolumn{2}{|c|}{ Post-Soviet integration } \\
\hline & Driving forces & $\begin{array}{c}\begin{array}{c}\text { Institutions and } \\
\text { outcomes }\end{array} \\
\end{array}$ & Driving forces & $\begin{array}{c}\begin{array}{c}\text { Institutions and } \\
\text { outcomes }\end{array} \\
\end{array}$ \\
\hline $\begin{array}{l}\text { 1991-1993/94: } \\
\text { Multilateral } \\
\text { bargaining in the } \\
\text { shadow of the } \\
\text { Soviet Union }\end{array}$ & $\begin{array}{l}\text { Multilateral } \\
\text { bargaining } \\
\text { between ethnic } \\
\text { republics and the } \\
\text { center with } \\
\text { attempts of non- } \\
\text { ethnic regions to } \\
\text { gain a more active } \\
\text { role }\end{array}$ & $\begin{array}{l}\text { Pure bargaining } \\
\text { federalism: } \\
\text { policies of each } \\
\text { region vis-à-vis } \\
\text { federal center } \\
\text { subject to constant } \\
\text { re-negotiations }\end{array}$ & $\begin{array}{l}\text { Multilateral } \\
\text { bargaining } \\
\text { between post- } \\
\text { Soviet countries } \\
\text { attempting to settle } \\
\text { the claims from the } \\
\text { Soviet Union and } \\
\text { establish closer } \\
\text { economic } \\
\text { cooperation }\end{array}$ & $\begin{array}{l}\text { Ruble Zone, } \\
\text { Commonwealth of } \\
\text { Independent } \\
\text { States: attempts of } \\
\text { close economic } \\
\text { cooperation or } \\
\text { even a new } \\
\text { federation } \\
\text { unsuccessful }\end{array}$ \\
\hline $\begin{array}{l}\text { 1993/94-2000/02: } \\
\text { Bargaining in } \\
\text { smaller clubs and } \\
\text { exchange of loyal } \\
\text { rhetoric for } \\
\text { preferential } \\
\text { treatment }\end{array}$ & $\begin{array}{l}\text { Bilateral } \\
\text { bargaining } \\
\text { between individual } \\
\text { regions and the } \\
\text { federal } \\
\text { government }\end{array}$ & $\begin{array}{l}\text { Asymmetric } \\
\text { federalism: } \\
\text { constitutionally } \\
\text { highly centralized } \\
\text { federation with } \\
\text { significant post- } \\
\text { constitutional } \\
\text { concessions and } \\
\text { unilateral } \\
\text { devolution of } \\
\text { individual regions }\end{array}$ & $\begin{array}{l}\text { Bargaining in } \\
\text { "smaller clubs" for } \\
\text { new regional } \\
\text { integration based } \\
\text { on the EU example }\end{array}$ & $\begin{array}{l}\text { CIS, EurAzEC, } \\
\text { OCAC, Union } \\
\text { State of Russia and } \\
\text { Belarus: ink on } \\
\text { paper integration } \\
\text { with high } \\
\text { ambitions (no } \\
\text { project achieved } \\
\text { even a free trade } \\
\text { area status) }\end{array}$ \\
\hline $\begin{array}{l}\text { 2000/02 - to date: } \\
\text { Divergent } \\
\text { development of } \\
\text { federalism and } \\
\text { integration } \\
\text { institutions }\end{array}$ & $\begin{array}{l}\text { Re-centralization } \\
\text { and restrictions on } \\
\text { regional politics }\end{array}$ & $\begin{array}{l}\text { Highly centralized } \\
\text { federalism with } \\
\text { limited authorities } \\
\text { of the regions and } \\
\text { strong hierarchy }\end{array}$ & $\begin{array}{l}\text { Attempts to } \\
\text { develop a "real" } \\
\text { functional } \\
\text { integration and to } \\
\text { increase Russia's } \\
\text { influence on } \\
\text { economy and } \\
\text { politics of the post- } \\
\text { Soviet countries }\end{array}$ & $\begin{array}{l}\text { Common } \\
\text { Economic Space: } \\
\text { completely } \\
\text { unsuccessful, } \\
\text { Russia's influence } \\
\text { in post-Soviet } \\
\text { countries } \\
\text { permanently going } \\
\text { down }\end{array}$ \\
\hline
\end{tabular}


Table 2: Strong and weak asymmetry and stability of alliances and federations

\begin{tabular}{|l|l|l|}
\hline International alliances & \multicolumn{1}{|c|}{ Strong asymmetry } & \multicolumn{1}{c|}{ Weak asymmetry } \\
\hline $\begin{array}{l}\text { Higher stability and } \\
\text { centralization through } \\
\text { hierarchy established by } \\
\text { the influential party }\end{array}$ & $\begin{array}{l}\text { Higher stability and lower } \\
\text { centralization through the } \\
\text { perceived threat } \\
\text { avoidance }\end{array}$ \\
\hline Federations & $\begin{array}{l}\text { Lower stability and } \\
\text { centralization through the } \\
\text { domino effect of } \\
\text { asymmetric concessions }\end{array}$ & $\begin{array}{l}\text { Possibly lower stability } \\
\text { and higher centralization } \\
\text { through the investments } \\
\text { of the federation }\end{array}$ \\
\hline
\end{tabular}

